\title{
【シンポジウム 17】
}

\section{身体活動促進とSDGs -多分野連携で進める研究と社会実装一}

\author{
井上 茂 ${ }^{1}$, 甲 斐 裕 ${ }^{2}$
}

( ${ }^{1}$ 東京医科大学公衆衛生学分野, ${ }^{2}$ 公益財団法人明治安田厚生事業団体力医学研究所)

身体活動の健康効果については, 数多くの研究が蓄積 されている。しかし, 不活動は世界的に蔓延し, 日本も 同様である.つまり，身体活動が健康に良いことはわかっ ているが，身体活動を促進させる手法に関する研究も実 践も十分とは言い難い状況である.WHOは2018年に「身 体活動に関する世界行動計画2018-2030（Global Action Plan on Physical Activity: GAPPA)」を発表し, 身体不 活動者を2025年までに10\%，2030年までに15\%減らす ことを目的に掲げた。GAPPAは, 身体活動の促進が, 国連の持続可能な開発目標 (Sustainable Development Goals: SDGs) のうち13の領域の促進にもつながること を示している.すなわち, 身体活動促進はSDG3（すべて の人に健康と福祉を）のみならず, SDG8（働きがいも 経済成長も), SDG11（住み続けられるまちづくりを）, SDG13（気候変動に具体的な対策を）等, 健康以外の複 数の領域でもべネフィットがあることを示している。そ して, 身体活動促進は単一の政策だけでは実現しないた
め, 健康やスポーツ分野だけでなく, 都市計画・交通等 のあらゆる分野と協力してシステムズアプローチとして 進めることを呼びかけている，以上のことは，日本にお ける身体活動促進の研究および社会実装を考えるにあた り，重要な視点である。

そこで本シンポジウムでは，はじめにGAPPA日本語 版を中心的に作成した慶應義塾大学の小熊祐子氏から GAPPAについて解説していただき, その後, 多分野と連 携して身体活動促進に取り組む研究事例を紹介する。建 築計画学・都市計画学分野から健康まちづくりについて 研究している千葉大学の花里真道氏, 地域住民を対象に防 災と身体活動促進を組み合わせて「防災体力」を提唱す る四国学院大学の片山昭彦氏, 企業と連携して勤労者の 座位行動の削減に取り組む体力医学研究所の北濃成樹氏 のそれぞれから話題提供をいただく.日本人の歩数・運動 習慣者ともに増加しない中で, 有効な打開策はあるのか? エビデンスをどう社会実装するのか？について考えたい.

\section{身体活動に関する世界行動計画2018-2030（GAPPA）の紹介と日本での展開について}

\author{
小 熊 祐子 ${ }^{1,2}$, 齋 藤 義 信 1,3 \\ ( 1 慶應義塾大学スポーツ医学研究センター, ${ }^{2}$ 慶應義塾大学大学院健康マネジメント研究科, \\ 3神奈川県立保健福祉大学イノベーション政策研究センター）
}

身体活動は多くの健康上の効果が認められているにも かかわらず，不活動者は世界的に増加している，蔓延す る身体不活動の問題に世界レベルでより積極的に取り組 むため, 世界保健機関 (WHO) は，2018年 6 月に身体活 動に関する世界行動計画2018-2030 (Global Action Plan on Physical Activity 2018-2030, GAPPA）を発表した. GAPPAでは，身体不活動者を2025年までに $10 \%, 2030$ 年までに $15 \%$ 減らすことを目標に揭げ，健康的で持続可 能な世界をつくるため,「アクティブな社会を創造」「ア クティブな環境を創造」「アクティブな人々を育む」「ア クティブなシステムを創造」という４つの戦略目標とそ れぞれの目標に $4-6$ 項目, 計 20 の政策措置が設定され ている。 これらの戦略目標及び政策措置はそれぞれ独立 したものではなく, 相互に関わり合っており, システム ベースのアプローチにより, コベネフィットを生み出し
得るものであり，各分野が協調して取り組むことで成し 得るものである。 アウトカムは健康だけでなく, 持続可 能な行動目標 (Sustainable Development Goals, SDGs) の多くの項目にもつながっていく，GAPPAでは身体活 動促進が13のSDGに貢献することに言及した，身体活 動促進の健康上の効果以外の指標として SDGs 達成の指 標も活用できる.

今後の身体活動促進を考えたとき，各レベルでステー クホルダーが集まりGAPPAを咀嚼し自分たちに合った システム図を描き, 実行・再評価・共有し, スケールアッ プしていく必要がある。日本では多分野で連携して身体 活動促進に取り組む例は少なくない，我々が関与してい る藤沢市も 1 例である. まずは先進例で, 当事者を集め システム図を描くこと, その作業自体が重要であり, 今 後の日本での展開について考えていく必要がある. 